\title{
NIGERIA-CAMEROON BORDER DEMARCATION AT A GLANCE AND LESSONS LEARNED FOR NEPAL
}

\author{
Mr. Prabhakar Sharma
}

Keywords: Border demarcation, international land disputes and settlements, WGS84 system, geodetic network, Nigeria-Cameroon border demarcation, Indo-Nepal border, Sino-Nepal border.

\begin{abstract}
The border demarcation between two countries usually takes place after wars or serious conflicts. Nigeria, which has the largest army in Africa, showed that it had a big heart when it reached an agreement with Cameroon as per the 2002 ICJ judgment without waging a war with its much smaller neighbor Cameroon. Although many Nigerians feel that Cameroon has gained a lot more than Nigeria, especially when Nigeria decided to hand over sovereignty of the $1000 \mathrm{sq}-\mathrm{km}$ oil-rich Bakassi peninsula to Cameroon, the Nigerian government is eager to make a closure of the boundary demarcation as per the 152-page ICJ judgment.
\end{abstract}

Ever since the demarcation activity started with a pilot project in 2005, many field missions have taken place with the mediation/facilitation of the United Nations, which has provided logistical and partial financial support and has brought in experts from all over the world.

The field demarcation along the land, river and ocean boundaries between Nigeria and Cameroon has mostly been completed, except for the final mapping and emplacement of boundary pillars along some sections of the border which are inaccessible or are marked 'disagreement areas'. There are some serious security threats posed by Boko Haram in the disagreement areas in the north.

The best practices used in the Nigeria-Cameroon border demarcation are outlined below. Nepal could take some valuable lessons from the demarcation methods used by these two countries and maintain the political will to carry on the border demarcation works which can be technically and physically challenging and politically complex.

\section{INTRODUCTION}

Nigeria and Cameroon share about $1950 \mathrm{~km}$ of boundary $(960 \mathrm{~km}$ of land boundary and $990 \mathrm{~km}$ of river boundary), starting from Lake Chad in the north all the way to Bight of Biafra in the easternmost part of the Gulf of Guinea.

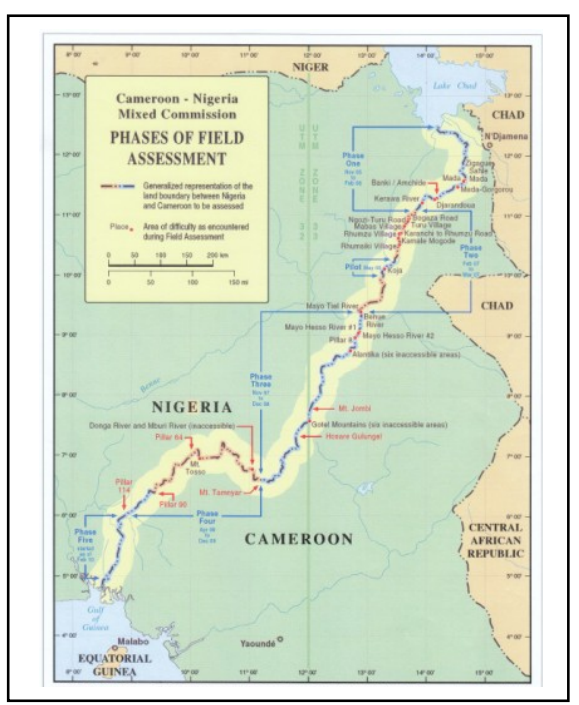

These two countries that had a few skirmishes in the past and nearly went to war are engaged in the orderly and peaceful implementation of the 2002 International Court of Justice (ICJ) Judgment regarding the land and maritime boundary between the two countries. They also established a MixedCommission to ensure implementation of the agreement. The Mixed-Commission holds regular meetings under the auspices of the United Nations.

So far, the Mixed Commission has agreed on the framework of the assistance provided by the UN, the timetable for the withdrawal of forces, the transfer of authority, the cost of demarcation, the budget and the fund-raising, the sequence of operations and the scope of work contracted out to the private sector. The Geneva Communiqué of 15 Nov. 2002 is the charter for the Mixed Commission.

Since its first meeting in December 2002, the Mixed Commission has met at regular intervals in the capitals of each country with the United Nations establishing a support team based at its Office for West Africa in Dakar, Senegal. 
The peaceful withdrawal and transfer of authority of over 30 villages in the Lake Chad area (in 2003) and along the land boundary in 2004 took place successfully under the supervision of United Nations civilian observers who were overseeing all these exercises.

The modalities governing the withdrawal and transfer of authority in the Bakassi peninsula were signed on 12 June 2006 in Greentree, New York. This agreement was signed by the presidents of Cameroon and Nigeria, the Secretary General and representatives of five witness countries-France, Germany, United Kingdom and the United States and by August 2006, as per the agreement, $80 \%$ of the peninsula was returned to Cameroonian administration with full withdrawal of Nigerian troops. The remaining $20 \%$ was handed over to Cameroon in June 2010.

On $11^{\text {th }}$ May 2007 an agreement was signed on the delimitation of the maritime boundary. The objective of this mission was to survey selected physical features in order to geo-reference the chart containing the boundary line as defined by the ICJ into the WGS84 datum.

In addition, the direction of the Loxodrome which forms the remainder of the maritime boundary up to its tri-point with Equatorial Guinea, was approved and signed in August 2007.

Hence all the four sections of the ruling-Lake Chad, the land boundary, Bakassi peninsula and maritime boundary- have been implemented peacefully.

\section{SUB COMMISSION ON DEMARCATION}

Alongside these more high profile legal and political issues, the process of demarcating the land boundary has continued with the Mixed Commission establishing a Sub-Commission on Demarcation (SCD) which in turn established a Joint Technical Team (JTT). The JTT includes technical experts from the UN, Cameroon and Nigeria responsible for carrying out the physical demarcation of the land boundary.

\section{PRELIMINARY MAPPING}

131 preliminary map sheets to 1:50,000 scales were prepared from partially rectified SPOT5 satellite imagery by the United Nations Cartographic section based in New York. These map sheets, which cover a $30-\mathrm{km}$ corridor on either side of the land boundary, are used for planning and field reconnaissance.

These maps will be augmented at a later date from the measurement of ground control points to fully rectify the imagery, leading to the production of the final mapping including the agreed boundary line.
A provisional boundary line based upon the delimitation instruments defined by the ICJ judgment is shown on the maps in conjunction with the SPOT imagery. This provisional line helps the surveyor in following the general direction of the boundary.

\section{FIELD ASSESSMENT}

In the field assessment, which is carried by the Joint Technical Team (JTT) according to the Technical Guidelines, the boundary is demarcated after agreeing on the location based on the terrain described in the ICJ judgment.

For each pillar location, a "pillar site template' on land or "river site template" on the river bank or on an island in the river, is used. On each site template, the GPS coordinates (UTM) based on Trimble Pro XRP with real time corrections from Omni-star are recorded, description cards prepared and signed by the delegations comprising of the UN, Nigerian and Cameroonian representatives. In general, pillars are placed at $500 \mathrm{~m}$ intervals, increasing to $100 \mathrm{~m}$ intervals in towns and villages.

In areas of disagreement, 'disagreement templates' with the comments of Nigerian or Cameroonian representatives are signed. There are 2 disagreement templates for each pillar site. The areas of disagreement are then referred to the SCD/Mixed Commission (MC) for a technical or even a political decision.

The UN provides helicopter support for the field assessment for inaccessible areas.

\section{GEODETIC NETWORK}

It was decided by the Parties to use the internationally-recognized WGS84 and UTM system for the land boundary work.

The Geodetic Network consists of the construction and survey of 10 primary markers more or less evenly spaced along the boundary in either country along with 30 secondary markers located closer to the boundary.

Primary markers were surveyed in 2007-2008 using GPS to an accuracy of $0.010 \mathrm{~m} \pm 1.0 \mathrm{ppm}$ (max error $0.100 \mathrm{~m}$ ) with the secondary markers to $0.020 \mathrm{~m}$ $\pm 10.0 \mathrm{ppm}(\max$ error $0.200 \mathrm{~m})$.

\section{BOUNDARY PILLAR EMPLACEMENT}

It is estimated that about 3000 pillars (500 primary and 2500 secondary pillars) will be required to complete the boundary. The primary pillars will be established at $5 \mathrm{~km}$ intervals and the secondary pillars 
will be constructed every 100 (for built up areas) or $500 \mathrm{~m}$.

The pillars will be constructed at the locations identified by the JTT during the field assessment.

\section{FINAL PILLAR SURVEY}

Following the construction of the pillars each one will be surveyed using DGPS(differential GPS) with the geodetic network forming the control points for the GPS survey. Each pillar will be surveyed to an accuracy of $0.020 \mathrm{~m} \pm 10.0 \mathrm{ppm}$ ( $\max$ error $0.200 \mathrm{~m})$.

A separate quality assurance contract will be undertaken to provide some assurance on the GPS computations for the geodetic network and the final survey.

\section{FINAL MAPPING}

The coordinates based on the final survey will be plotted on the rectified (using the ground control survey) 1:50,000 mapping.

\section{LESSONS LEARNED FROM NIGERIA- CAMEROON BORDER DEMARCATION APPLICABLE TO NEPAL-INDIA OR NEPAL-CHINA BORDER DEMARCATION AND MAINTENANCE}

The Nigeria-Cameroon border demarcation activity is viewed as one of the most successful on-going demarcation works in the world. It is, however, not without its own share of problems. The emplacement of pillars, especially along the northern NigeriaCameroon border, has been stalled because of security concerns due to Boko Haram. There are also issues related to the inaccessibility of the terrain. The inaccessible areas, especially the high mountains of Atlantica and Gotel ranges, were demarcated in the office and the templates with derived coordinates and description cards were signed based on DEMs (Digital Elevation Models) from satellite imagery.

Based on the experience of working for 8 years in the international border demarcation works along the Nigeria-Cameroon border, the author proposes the following:

- The WGS 84 and UTM system is one that can be used for border demarcation and reconstruction works for the Nepal-India or Nepal-China border with XRP Trimble GPS units with Omni-star subscription to obtain real time coordinates to successfully identify missing pillars or to trace old river courses or for densification of pillars along the boundary. The XP Omni-star observation gives real time coordinates with differential correction to subdecimeter accuracy in open areas. For forested areas that do not have a clear line of sight to the Omni-star satellites, the dual frequency differential GPS (DGPS) method that uses a base and a rover station should be used.

- Nepal and India agreed to restart the stalled border maintenance and restoration works during Indian Prime Minister's visit to Nepal in the first week of August 2014. The border demarcation between Nepal and India will soon take place in a spirit of friendship and mutual respect as the leaders of both countries have shown the right political will to solve the border issues. We share about $1808 \mathrm{~km}$ open border with India with whom we have cultural, religious, linguistic and traditional ties. We should make concerted efforts to solve remaining border issues between our two countries.

As it is a well-known fact that boundary maintenance and restoration are important contributors to continuous boundary stability, the GoN should establish well-funded National and International Boundary Commissions to solve the pending issues regarding national and international boundaries.

- It is very important to establish map libraries and archives of all the treaties, documents, individual and mutual maps of the treaties, aerial photographs, satellite imagery, articles by border experts (geodesists, cartographers, mapping experts and geographers) and politicians and lawyers so that they can be studied before we send in delegations at the international and national levels for negotiations of international or state boundaries.

- The GoN and the boundary commissions should send the technical and political experts to ferret out from the archives of other countries information regarding Nepal's border during British rule in India. The technical experts should be sent on trainings both at the local and international levels so that they can get the technical know-how of the best practices in border delimitation, demarcation, construction, maintenance and restoration works. There should also be transfer of local and international knowledge gained by Nepali experts to the 
younger generation by organizing workshops and seminars and paper presentation.

- Nepal and India would benefit greatly if there is a joint list of boundary coordinates in a common geodetic system, such as the WGS 84 GPS system which uses the UTM projection. It would be advantageous for Nepal to establish a GPS network all over the country so that it can be used not just for engineering surveying works and hydropower development but for boundary demarcation works and a long-term monitoring of the heights of Mount Everest and other high mountain peaks by local and international experts and researchers using different models and technological developments.

\section{References:}

Adler, R. (1995) Positioning and Mapping International Land Boundaries, Boundary and Territory Briefing 2(1), IBRU, Durham.

Anglo-German agreements of 11 March and 12 April 1913.

Brown, H. (1994) The Iraq-Kuwait Boundary Dispute: Historical Background and the UN Decisions of 1992 and 1993, IBRU Boundary and Security Bulletin 2(3), October 1994, 66-80.

Shrestha, B. N. (2009) Border Issues of Nepal.

Thapa, K. (2009) Nepal Must Fix Its Border Using GPS Technology.

2002 ICJ judgment regarding the land and maritime boundary between Nigeria and Cameroon.

Thomson-Marchland Declaration, 1929-1930 (incorporating the Moisel map of 1912).

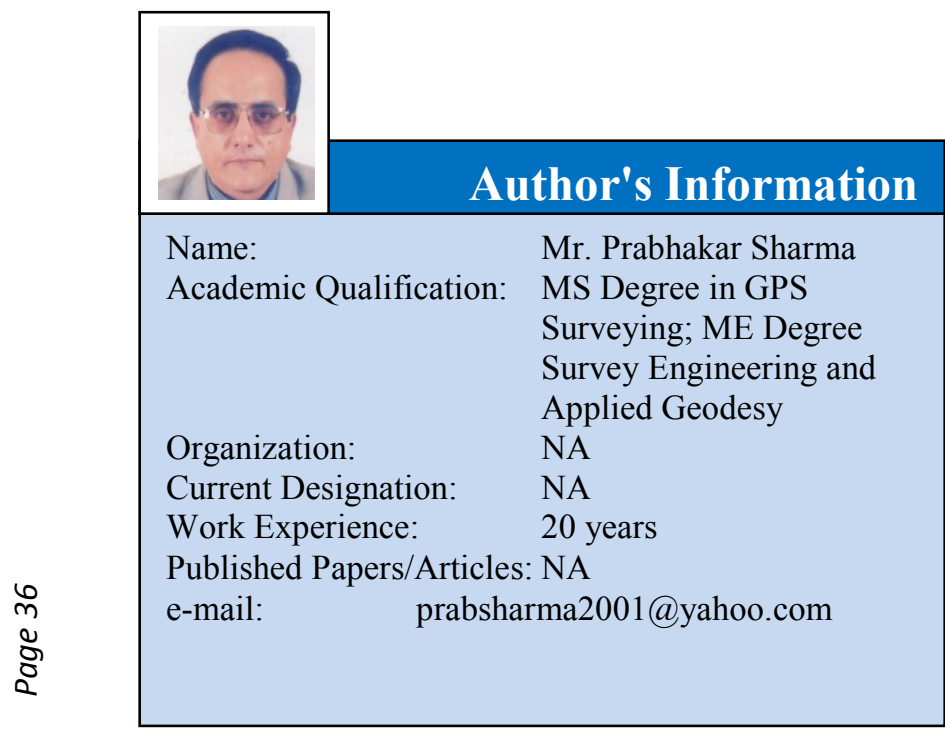

